Vol. XXV No 2019

\title{
CONTEMPORARY TRENDS IN THE DEVELOPMENT OF THE ANTI- CORRUPTION LEGISLATION OF REPUBLIC OF BULGARIA
}

\author{
Vladislav KRASTEV, Blagovesta KOYUNDZHIYSKA-DAVIDKOVA, \\ Nadezhda PETKOVA
}

\author{
"Neofit Rilski" South-West University, Blagoevgrad, Bulgaria \\ vladislav_swu@law.swu.bg, vesi_8808@abv.bg, nadya.petkova@abv.bg
}

\begin{abstract}
In 2000, the global policy against the phenomenon of "corruption" was launched by the United Nations, and in 2003 the United Nations Convention against Corruption (UNCAC) was adopted, which Bulgaria ratified three years later. Two months after the adoption of this international convention, Bulgaria became part of the European Union. The accession was accompanied by the creation of "specific accompanying measures" aimed at correcting identified deficiencies in various areas, including measures against corruption. As a result of the annual reports of the European Commission on Bulgaria's progress on the Co-operation and Verification Mechanism, anti-corruption law-making has begun to develop and improve. Serious progress in this direction is the creation of legislation in the area of "conflict of interest", which is not exactly corruption but creates prerequisites for its development, especially in the public sphere. The paper presents the result of the analysis of the created anti-corruption legislation after the accession of the Republic of Bulgaria to the EU. Particular attention is paid to the law adopted in 2018 regulating anti-corruption measures, as well as the terms and procedure for the seizure of illegally acquired property for the benefit of the state.
\end{abstract}

Keywords: corruption, Bulgarian anti-corruption legislation, conflict of interests, bribe

\section{Introduction}

The theme of the "corruption" phenomenon will always be relevant to the public. On the one hand, in their desire for development, realization, career growth and good financial status, an official pursues their objectives and defends his or hers interests, and on the other hand they must defend public interest by the optimal distribution and most appropriate expenditure of state or municipal resources. When officials are positioned at the lowest level of ,the Maslow pyramid", then the probability that they would abuse their power is the greatest. This may be a prerequisite for the widespread occurrence of corruption in countries with a weak economy.
Corruption is a complex social, political and economic phenomenon which can be found in both private and public sectors. [1]. Over the years numerous attempts were made globally to give a comprehensive legal definition of "corruption", but so far no one has managed to put an encompassing definition of this undesirable phenomenon. Despite the various forms of government, the different legal systems, different social, political and economic levels of development of individual societies, corruption is a common problem, the solution for which requires a global policy that would unite all countries. The United Nations Convention against Corruption was established due to the 
endangerment of the stability and security of societies, of the values of democracy, of the ethical values and justice that threaten sustainable development and the rule of law. Moreover, corruption, as a phenomenon, endangers the political stability and the sustainable development of countries [2].The balance may be disturbed by the increasing mistrust of people in the three state authorities. When a nation, a society loses their trust in the impartial activity of the state or municipal authorities, then the erosion in public confidence starts and the reinforcement in the negative attitude towards the state as well.

The democratic form of government of the Republic of Bulgaria brings forward the society and the state is supposed to look after its necessities [3]. Therefore the satisfaction, the guarding and protecting of the public interest must be one of the top priorities of the state authority. According to N. Naydenov [4], the access to management and the disposition of public resources is an abstract prerequisite for their misuse. The morality of those who are authorized to administer public funds or provide public services comprises the greatest danger for the misuse with this public interest. The basis of the problem lays in the fact that these people have their own personal interest, which in certain situations outweighs the one of the public and thus it becomes private interest.Selfinterest in itself is not reproachable but in case it conflicts public interest and this results in the creation of private interest, then a wrongful act is formed resulting in the person bearing means of power or the ones related to them benefiting from this process. If this process is not avoided and the people are not correspondingly punished, this would act as a signal to society that this practice, despite being a vicious one, is not punishable.

The presence of private interest and the circumvent of basic fundamental principles of the modern democratic society can have a very serious impact on economic initiative as the main mechanisms for prevention of monopoly misuse, of unfair competition and of customers' protection may not be put to work.

Here it should also be taken into account the Index for Corruption Prevention developed by Transparency International [5], related to the level of corruption in the Republic of Bulgaria which is considered to be an abuse of public positions for personal gain. The data on the level of corruption in a given country are summarized on the basis of the opinion of business representatives, analysts and interviewed experts. In the period between 2012 and 2018 the values were within the $41-43 \%$ landmark which shows a relatively constant presence of corruption in public life.

\section{Anti-corruption legislation}

From 2005 to 2007 natural changes occurred in the Bulgarian legal system which started firstly with amendments in the Constitution and later affected almost all existing legal acts with the aim being unification with the European legislation. One of the main concerns of the European Union in regards to the Republic of Bulgaria is the insufficiently well acting anti-corruption policy with its corresponding anti-corruption legislation and state authorities responsible for the prevention and the disclosure of persons involved with corruption-related schemes and their corresponding punishment. Bulgaria undertook a serious commitment to work towards the creation of mechanisms which would limit the unwanted phenomenon of "corruption" by joining the European Union. The first step in this direction is the establishment of a mechanism for cooperation and verification of the progress through which indicative benchmarks are set that would allow for the easier monitoring in this area. The concerns of the European Commission (EC) are that without an irreversible progress on the judicial reform in the fight against corruption and organized crime, the 
Republic of Bulgaria risks not being able to apply rightfully EU laws [6].

The assessment is made on the basis of indicators which are few in number. Firstly, the European Commission requires for a judicial reform to be made through which the independency and accountability of the judicial system would be guaranteed. Next, attention must be paid to the allegations in corruption at high levels, to the necessity of internal inspections of public institutions and to the publication of the assets of highranking officials. It should be mentioned in this context that in Bulgaria a Law on Publicity of High-Ranking Officials' Assets was promulgated in 2000 which was an obvious indicator for the willingness of the state to deal with the phenomenon of "corruption".

In 2008 in the Republic of Bulgaria was created the first Law on Counteraction and Revealing Conflict of Interest (repealed) (LCRCI), through which a legal definition for the term "conflict of interest" was established and through which the real fight against this phenomenon began. Despite the fact that the conflict of interests is not identical to the "corruption" phenomenon, it creates a favorable environment for the development of corruption practices resulting in the public interest being neglected over personal interest. The law became a starting point for the use of a fully decentralized control mechanism for corruption control. It acted only in relation to the category of people who occupy a public office which is covered in art. 3 and throughout the years has constantly been supplemented.

The strategy of the legislature to create multiple commissions responsible for the application of the law turned out to be a complete failure which was also proven by the judicial practice. The main issue is the controversial interpretation of the text of the law as well as the various methods for establishing the conflict of interests.Thus for example; there were different proceedings for the various public offices before the Supreme Administrative Court, the Supreme Judicial Council, the municipal councils and the authority election or appointment. As a result from the created legislative chaos, a new centralized method for the management of the conflict of interest was applied in 2010 which began to give the expected by the EC results. An independent five-member commission authorized to establish and sanction the persons occupying public positions in case of establishment of conflict of interests amongst them was created and the contestation procedure was before the Administrative Court in the city of Sofia. The law's contribution in the fight against corruption is expressed in the created prohibitions imposed in the exercise of public office, the obligation to declare incompatibility and private interests, as well as some restrictions for the persons occupying a public office after their release from office.

The law underwent nine amendments in the forthcoming years and was abolished in the beginning of 2018. As a result of the work of the Committee for Prevention and Ascertainment of Conflict of Interests (CPACI) it is established that for the period between June 2011 and December 2017 1988 administrative proceedings were instituted before it and it ruled against 2478 people [7]. The imposed sanctions amounted to 2195 040, 38 BGN which are less than the commission's two-year allowance. The fact that these are imposed sanctions and not budget funds should be taken into account.

The Law for the State's Forfeiture of Unlawfully Acquired Property (LSFUAP) (repealed), which came into force in 2012, turned out to have considerable contribution for tackling the phenomenon "corruption". Its creation is a decisive step towards overcoming the deficit of anti-corruption measures in Bulgarian legislation which would stop or at least limit the opportunities before organized crime to be a source of corruption. A legal mechanism that would 
limit the possibilities for the accumulation of illegal wealth in order for the state's and the public's interests to be effectively protected was created. The commission, authorized under this law, is a collective state body the chairman of which is appointed by the Prime Minister and its members - by the members of the National Assembly. For the period after the entry into force of LSFUAP from 19/11/2012 until the end of 2018 the value of the property offered for collateral in total amounts to 2859824940,56 BGN, according to the 433 requests for imposing security measures [8]. The commission's budget for this period amounts to 31 051424 BGN with the budget for 2018 not being included due to the repeal of the law. In the beginning of 2018 the Law on Counteracting Corruption and Forfeiture of Unlawfully Acquired Property (LCCFUAP) came into action and merged LSFUAP, LCRCI and the Law on Publicity of Assets of Persons Holding Higher State and Other Positions (LPAPHHSOP). The new law is proof for the enhanced anti-corruption policy. On the basis of data provided for the two main laws protecting the public interest from corruption the effectiveness of LCCFUAP is higher many times over. This is also the reason why the new anticorruption law should use the proven effective mechanisms of LSFUAP and specifically when it comes to the structure of the new anti-corruption body. The law requires in this regard that the chairman of the commission must be chosen through a vote by the National Assembly and his/her deputy and the other three members of the commission to be elected by the National Assembly at his/her proposal.

The main goal of LCCFUAP is to protect the society's interest by effectively counteracting corruption, ensuring that high-ranking officials perform their duties honestly and in compliance with the Constitution and with the laws and prevent the possibility of illegal acquisition of property and its disposal. A legal definition for the term "corruption" is also created which, within the meaning of art.3, par. (1) of the Law is "present when in result of a high-ranking public office, the public official misuses their power and does not perform official duties with the purpose of directly or indirectly retrieving undue material or non-material goods for themselves or for other people“. The commission is given the opportunity to make a request for the use of special intelligence means under conditions and in accordance with the procedure established by the Special Intelligence Means Law in order to achieve higher efficiency.

Last but not least, the power of the commission to establish a conflict of interests in regards to people occupying high-ranking positions which have been listed in art.6, par. (1) of LCCFUAP should be outlined.

The law has significant advantages over all other legal instruments created to counteract corruption. Significant attention is paid to prevention, which results in the commission collecting, aggregating and analyzing national and European anticorruption policies and at the same time collecting and compiling good practices, which are then used to develop anticorruption measures. The commission also develops methodologies for assessing corruption risk, ethical standards of conduct, verification systems integrity and assists their implementation. The main function of the committee is to organize training seminars and information campaigns that are inclined towards tackling corruption.

Analyzing public policy related to counteracting corruption, a reluctance of the judicial system to be reformed is observed. LCCFUAP refers to the Law on the Judiciary Power in case inspections on declarations of assets of judges, prosecutors, investigators, the chairmen of the SCC and the SAC, the Attorney General, administrative heads of judicial bodies and their deputies must be made. In 
2017 inspections of about 4000 magistrates of integrity and conflict of interest began pursuant to the Rules of Organization of the Inspectorate to the Supreme Judicial Council and the one of the administration and experts.

In 2011 the EC [9] found that the judicial inspectorate not always investigates allegations against magistrates, and if there are any disciplinary sanctions, they are mild. The finding that the prosecution does not begin regular criminal investigations against magistrates when allegations of corruption are made, which contribute to the erosion of public confidence in the judiciary, is disturbing. The commission analyzes the progress of the Republic of Bulgaria concerning the judicial system from 2007 to 2012 the following year. Despite the positive feedback about the overall state policy in this area the efficiency of the judiciary is criticized. The result from the conducted monitoring shows that there are inconsistencies; decisions are not taken or a deterrent effect has not been reached. The findings in this direction continue in the following years - the number of disciplinary proceedings increases, however, the number of successful appeals does as well. Measures to improve practices in the judicial system are evaluated as superficial and ones that do not provie real results. Major changes occur in 2017-2018 that affect the Supreme Judicial Council (SJC), which are rated by the EU as positive and effective; as such that will increase public confidence in the system. The Inspectorate with the Supreme Judicial Council was favorably assessed for its activities related to counteracting corruption in the judicial system and to the development of an electronic system for receiving and processing complaints and reports of corruption in the judiciary.

Corruption is often associated with bribery which according to art.301, par. (1) happens when an official requests or accepts a gift or any benefit which he or she is not due of, or when they accept an offer or a promise of a gift or benefit in order to perform or not to perform their duties or because of a similar action.

Currently, the challenge before the SCC is the development of an interpretative decision with which the accumulated controversial judicial practice to be discontinued. It is related to the interpretation of the active bribery under art.304 and art.304a of the PC when the act of execution has been carried out in the form of "offer" or "give" in the cases when the gift or benefit has not been accepted by the official it was intended for.

An analysis carried out on judicial practice in the period 2011-2018 results in the establishment of the fact that Bulgarian courts accept the occurrence of a carried out attempt for a crime committed as such because the executed act of "giving" a gift or benefit is completed but due to reasons beyond the perpetrator the socially dangerous consequences did not occur - the official, which the bribe was intended for, did not accept it. A total of 76 rulings and convictions are ruled out in the period 2012-2018 in this regard.

In other rulings, which are comparatively fewer in number, the court accepts the circumstance that the official the bribe was intended for did not accept it; the completion of an active bribe has not been established because it was completed with the act of giving the gift or the benefit.

Furthermore, 60 rulings and convictions of courts are ruled out where the bribe is considered as complete when the gift or benefit are made available and in the actual authority of the official they are intended for with his or hers following actions concerning the acceptance are not taken into account.

\section{Conclusions}

The paper does not claim to be exhaustive in terms of all the legislative changes related to the conducted Bulgarian anticorruption policy. The improvement of the anti-corruption legislation is an on-going 
process. The purposeful creation of legal constraints through the discontinuation of corrupt practices and the conflict of interests should have significant impact given the resources that allocated for them. There has been a strong state policy against corruption carried out by the legislative, executive and judiciary authorities in the last two years. It is related to the refinement of the acting legislation, however despite these efforts and the achieved positive results, the public's opinion on the "corruption" phenomenon remains relatively constant This in itself casts doubt on the effectiveness of the institutions authorized to limit its dissemination and to disclose and sanction the people misusing their power for personal benefit or for the benefit of people related to them.

\section{References}

[1] E. Commission, European Semester Thematic Factsheetearly School Leavers, 2017.

[2] UN, United Nations Convention against Corruption, New York, 2004.

[3] Constitution of The Republic Of Bulgaria, 1991.

[4] N. Naydenov, Basic elements of corrupt action vs. a universal definition of corruption, Public Policy.bg, vol. 2, no. 4, pp. 13-45, 2011.

[5] Corruption Perceptions Index, https://www.transparency.org/research/cpi/overview.

[6] Report from the Commission to the European Parliament and the Council on Bulgaria's progress on accompanying measures following Accession, 2007. https://eurlex.europa.eu/legal-content/EN/TXT/HTML/?uri=CELEX:52007DC0377\&from=BG.

[7] Annual Reports of CPACI 2011-2017

[8] Annual reports from the commission on the recovery of illegally acquiredp roperty. http://www.ciaf.government.bg/pages/view/godishni-dokladi-56/.

[9] Report from the Commission to the European Parliament and the Council on Bulgaria's progress on accompanying measures following Accession, https://eurlex.europa.eu/legalcontent/EN/TXT/HTML/?uri=CELEX:52007DC0377\&from=BG., 2011. 